\title{
ESTIMATION OF TENSILE STRENGTH PARALLEL TO GRAIN OF WOOD SPECIES
}

\author{
André L. Christoforo ${ }^{1 *}$, Tulio H. Panzera ${ }^{2}$, Francisco A. R. Lahr ${ }^{3}$ \\ ${ }^{1 *}$ Corresponding author. Universidade Federal de São Carlos (UFSCar)/ São Carlos - SP, Brasil. \\ E-mail: christoforoal@yahoo.com.br | ORCID ID: http://orcid.org/0000-0002-4066-080X
}

\section{KEYWORDS}

Tensile Strength, Wood, Hardwood, Least Square Method.

\begin{abstract}
According to the ABNT NBR 7190: 1997 standard, tensile strength of wood samples shall be defined as the ratio between the ultimate strength from a stress test and the specimen cross-sectional area $\left(350 \mathrm{~mm}^{2}\right)$. However, due to the complex wood anatomy and experimental difficulties, the fractured surface in tested samples are not perpendicular to the loading direction; therefore, such fractured surface becomes larger than the sample cross section, overestimating tensile strength by this method. Using an alternative approach, we aimed to determine the approximate fracture surface of wood specimens subjected to tensile test. For this purpose, we used the least square method to estimate tensile strength of four hardwood species, which were equally divided into strength classes. Then, we determined the relationship between the cross-sectional areas of intact and fractured specimens. The results showed that the approximate area of a fractured surface was 2.14 higher than that of an intact sample. As a result, tensile strength estimates were $47 \%$ lower than those currently estimated, which is unfavorable for the safety of construction structures.
\end{abstract}

\section{INTRODUCTION}

Wood is a renewable resource, abundant in Brazil, and presents a high relationship between mechanical strength and density, which makes it suitable for use in building structures (Molina \& Calil, 2015, Cavalheiro et al., 2016, Kain et al., 2017). As an orthotropic material, wood shows different mechanical properties in longitudinal, radial, and tangential directions (Lahr et al., 2014, Stolf et al., 2016). It has motivated some researches focused on evaluating the association of wood properties and specific positions of samples under mechanical tests (Icimoto et al., 2015; Christoforo et al., 2017).

The combination of cellulosic fibers (resistant and flexible) and lignin (biological fiber binder) categorizes wood as a fibrous composite material (Dai \& Fan, 2014, Tao et al., 2017, Youjun et al., 2017). Under a static bending test, this material exhibits an increasing R-curve for cracks due to mechanisms able to prevent crack from opening in mode I. This is evidenced by fiber layers that enable the development of cracks not only towards the load direction in a test but also perpendicular thereto (i.e., mixed mode). Therefore, wood anatomical composition makes it a highly tough material resistant to crack propagation (Morel \& Valentin, 2005, Stolf et al., 2015, Xianwu et al., 2017, Fank et al., 2017).

In Brazil, structural projects are elaborated following assumptions and calculation methods described in the Brazilian Standard ABNT NBR 7190: 1997 (ABNT, 1997), which defines design criteria and testing methods to determine physical and mechanical properties of wood materials for structural purposes. According to this standard, wood tensile strengths $\left(\mathrm{f}_{\mathrm{t}}\right)$, either parallel $\left(\mathrm{f}_{\mathrm{t}}\right)$ or perpendicular $\left(\mathrm{f}_{\mathrm{t} 90}\right)$ to grain directions, are defined as the ratio between the ultimate strength from a static tensile test $\left(\mathrm{F}_{\max }{ }^{\mathrm{t} 0}, \mathrm{~F}_{\max }{ }^{\mathrm{t} 90}\right)$ and the sample cross-sectional area (S), as expressed in eqs (1) and (2), respectively.

$$
\begin{aligned}
& f_{t 0}=\frac{F_{\max }^{t 0}}{S} \\
& f_{t 90}=\frac{F_{\text {max }}^{t 90}}{S}
\end{aligned}
$$

\footnotetext{
${ }^{2}$ Universidade Federal de São João del-Rei (UFSJ)/ São João del-Rei - MG, Brasil.

${ }^{3}$ Escola de Engenharia de São Carlos (EESC), Universidade de São Paulo (USP)/ São Carlos - SP, Brasil.

Received in: 10-23-2017
}

Accepted in: 4-22-2019 
In both eqs (1) and (2), fracture is considered to occur at mid-length of specimen, and the fractured area is assumed to be perpendicular to load direction. However, due to inherent characteristics of wood and a non-uniform growth of its longitudinal fibers (anatomical defects), fracturing mechanism does not occur in a single direction (Dai \& Fan, 2014); hence, the cross-sectional area of a fractured sample tends not to be perpendicular to fiber direction, as shown in Figure 1.

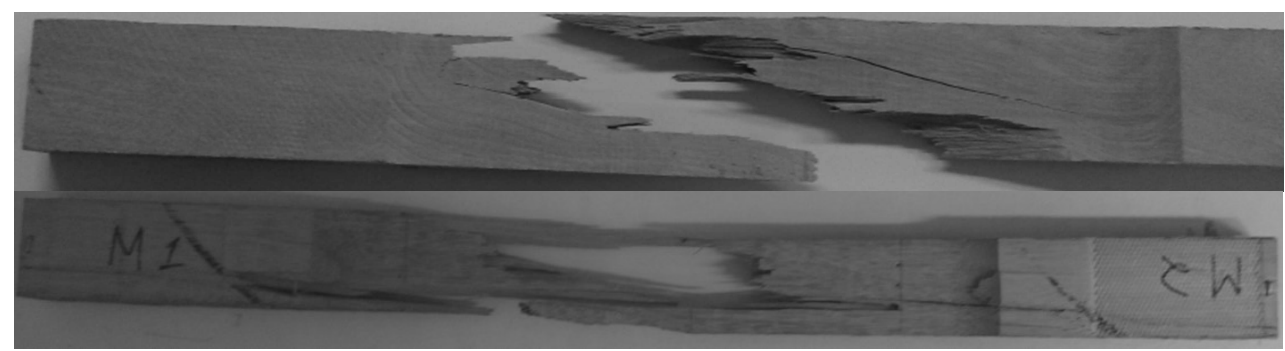

FIGURE 1. Wood specimens fractured in tensile strength tests in parallel to grain direction.

Figure 1 shows that the surface of a fractured area of the specimen is larger than its cross-sectional area (nominal $-7 \mathrm{~mm} \times 50 \mathrm{~mm}$ ). Under these conditions, the use of eqs (1) and (2) to determine tensile strength, as in ABNT NBR 7190: 1997 (ABNT, 1997), may result in strength values higher than those obtained by considering the area of the fractured section, thereby undermining the safety of structural projects.

The present study proposes an approximate calculation of the cross-sectional area of fractured specimens in a tensile strength test in parallel to grain direction, using the least square method (linear regression model) to relate this approximate area to the specimen nominal area. For this purpose, four wood species of hardwood trees, equally divided into strength classes, were tested, in addition to propose a coefficient $(\alpha)$ to be incorporated into [eq. (1)] of the above-mentioned Brazilian standard.

\section{MATERIAL AND METHODS}

Wood species used in this research were Cedrorana (Cedrelinga catenaeformis), Canafístula (Cassia ferruginea), Tatajuba (Bagassa guianensis), and Maçaranduba (Manilkara huberi). The wood materials were properly stored with about $12 \%$ moisture content, established as equilibrium content by the Brazilian standard ABNT NBR 7190: 1997 (ABNT, 1997). All mechanical property tests were carried out in the Laboratory of Wood and Timber Structures (LaMEM/SET), in the School of Engineering of São Carlos (EESC), University of São Paulo (USP), São Carlos - SP, Brazil.

According to the ABNT NBR 7190: 1997 (ABNT, 1997), wood strength classes are based on characteristic values of compression parallel to grain $\left(f_{\mathrm{c} 0}, \mathrm{k}\right)$, as shown in [eq. (3)].

$f_{c 0, k}=\left(2 \cdot \frac{f_{1}+f_{2}+f_{3}+\ldots+f_{(n / 2)-1}}{(n / 2)-1}-f_{n / 2}\right) \cdot 1.10$
To use [eq. (3)], the strength values $\left(f_{i}\right)$ obtained from specimens should be placed in ascending order $\left(f_{1} \leq f_{2} \leq f_{3} \ldots \leq f_{n}\right)$, discarding the highest one if the number of specimens is odd, for not accepting a $f_{c 0, k}$ below $f_{1}$, nor less than $70 \%$ of the average value. From each wood species, 12 specimens were prepared and then subjected to parallel-to-grain loading. Table 1 presents the characteristic strengths from parallel-to-grain tensile strength tests for each wood species and its respective hardwood class. This emphasized that selecting a species by its strength class allows a greater comprehension of coefficient $\alpha$, to be obtained by the least square method.

TABLE 1. Relationship between wood species and strength classes of hardwood group.

\begin{tabular}{ccc}
\hline Specie & $\mathrm{f}_{\mathrm{c} 0, \mathrm{k}}(\mathrm{MPa})$ & Strength Class - C \\
\hline Cedrorana & 69.3 & $\mathrm{C} 20$ \\
Canafístula & 76.2 & $\mathrm{C} 30$ \\
Tatajuba & 98.1 & $\mathrm{C} 40$ \\
Maçaranduba & 126.4 & $\mathrm{C} 60$ \\
\hline
\end{tabular}

To determine the approximate area of a fractured region $\left(\mathrm{S}_{\mathrm{EF}}\right)$, one of the fractured parts of a specimen is chosen; then, a reference system is established on the chosen part to obtain the following coordinates of the region vertices: $\mathrm{A}\left(\mathrm{x}_{\mathrm{A}}, \mathrm{y}_{\mathrm{A}}, \mathrm{z}_{\mathrm{A}}\right), \mathrm{B}\left(\mathrm{x}_{\mathrm{B}}, \mathrm{y}_{\mathrm{B}}, \mathrm{z}_{\mathrm{B}}\right), \mathrm{C}\left(\mathrm{x}_{\mathrm{C}}, \mathrm{y}_{\mathrm{C}}\right.$, $\left.\mathrm{z}_{C}\right)$, and $\mathrm{D}\left(\mathrm{x}_{\mathrm{D}}, \mathrm{y}_{\mathrm{D}}, \mathrm{z}_{\mathrm{D}}\right)$, as shown in Figure 2 .

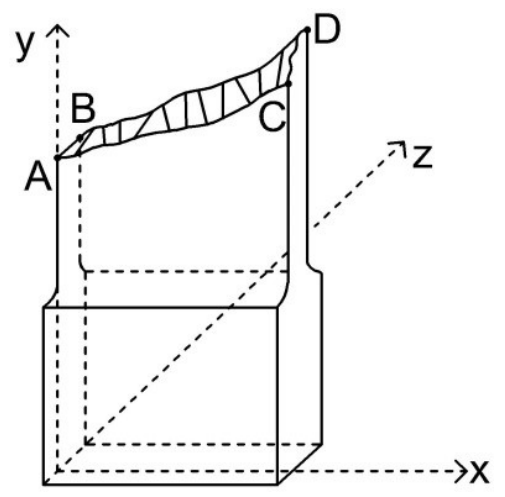

FIGURE 2. Coordinate system diagram of points (A, B, C, and D) at fractured surface vertices. 
From linear algebra, it is known that the vector product norm $(\times)$ between two vectors $\stackrel{\mathbf{l}}{1}_{1}=1_{1 x} \cdot \stackrel{\mathbf{I}}{i}+1_{1 y} \cdot \stackrel{\mathbf{I}}{j}+1_{1 z} \cdot \stackrel{\mathbf{I}}{k}$ and $\stackrel{\mathbf{l}}{1}_{2}=1_{2 x} \cdot \stackrel{\mathbf{I}}{\boldsymbol{i}}+1_{2 y} \cdot \stackrel{\mathbf{l}}{j}+1_{2 z} \cdot \stackrel{\mathbf{l}}{\boldsymbol{k}}$ is numerically equal to the area of the polygonal region (S) generated between both $S=\left\|1_{1}^{\mathbf{I}} \times \mathbf{1}_{2}\right\|$, as expressed in [eq. (4)].

$$
\begin{aligned}
& S=\left\|\operatorname{det}\left[\begin{array}{ccc}
\mathrm{r} & \mathrm{r} & \mathrm{r} \\
i & j & k \\
1_{1 x} & 1_{1 y} & 1_{1 z} \\
1_{2 x} & 1_{2 y} & 1_{2 z}
\end{array}\right]\right\| \Rightarrow \\
& \Rightarrow S=\sqrt{\left(1_{1 y} \cdot 1_{2 z}-1_{1 z} \cdot 1_{2 y}\right)^{2}+\left(1_{1 z} \cdot 1_{2 x}-1_{1 x} \cdot 1_{2 z}\right)^{2}+\left(1_{1 x} \cdot 1_{2 y}-1_{1 y} \cdot 1_{2 x}\right)^{2}}
\end{aligned}
$$

Equation 4 was applied to each vertex of the fractured region of a given specimen (Figure 2), obtaining the approximate area considering the following vertices: $\mathrm{A}\left(S_{e f}{ }^{A}=\|\bar{A} \bar{B} \times \bar{A} \bar{C}\|\right), \mathrm{B}\left(S_{e f}{ }^{B}=\|\bar{B} \bar{A} \times \bar{B} \bar{D}\|\right), \mathrm{C}\left(S_{e f}{ }^{C}=\|\bar{C} \bar{A} \times \bar{C} \bar{D}\|\right)$, and $\mathrm{D}\left(S_{e f}{ }^{D}=\|\bar{D} \bar{B} \times \bar{D} \bar{C}\|\right)$. The effective specimen area to be used in [eq. (1)] is the highest among the following values: $\mathrm{S}_{\mathrm{ef}}^{\mathrm{A}}$, $\mathrm{S}_{\mathrm{ef}}^{\mathrm{B}}, \mathrm{S}_{\mathrm{ef}}{ }^{\mathrm{C}}$, and $\mathrm{S}_{\mathrm{ef}}^{\mathrm{D}}$, wherein: $\mathrm{S}_{\mathrm{ef}}=\max \left(\mathrm{S}_{\mathrm{ef}}^{\mathrm{A}}, \mathrm{S}_{\mathrm{ef}}^{\mathrm{B}}, \mathrm{S}_{\mathrm{ef}}{ }^{\mathrm{C}}, \mathrm{S}_{\mathrm{ef}}{ }^{\mathrm{D}}\right)$.

Since the failure plane is not perpendicular to the applied loading direction (Figure 1), tensile strength consists of the total or effective stress, which has normal and shear stresses as components.

Additionally, 12 specimens were prepared for each wood species and subjected to parallel tensile tests. Once the approximate area $\left(\mathrm{S}_{\mathrm{ef}}\right)$ and cross-sectional area of each specimen [S] (nominal dimension - 50mm 7mm) were determined, the least square method (Equation 5) was used to obtain an optimal coefficient $(\alpha)$, which expresses the relationship between both areas $\left(\mathrm{S}_{\mathrm{ef}}=\alpha \cdot S\right)$, considering sample results of the four wood species.

$$
f(\alpha)=\frac{1}{2} \sum_{i=1}^{n}\left(S_{e f, i}-\alpha \cdot S_{i}\right)^{2}
$$

\section{RESULTS AND DISCUSSION}

Table 2 presents the means $(\bar{x})$ of approximate area $\left(\mathrm{S}_{\mathrm{ef}}\right)$, cross-section area $(\mathrm{S})$, parallel-to-grain tensile strength test by ABNT NBR 7190: $1997\left[\mathrm{f}_{\mathrm{t} 0}{ }^{\mathrm{ABNT}}\right]$, tensile strength based on the approximate area $\left(\mathrm{f}_{\mathrm{t} 0} \mathrm{ef}\right)$, as well as the coefficients of variation $(\mathrm{CV})$ and respective confidence intervals (CI) (95\% confidence) for each wood species.

\begin{tabular}{|c|c|c|c|}
\hline \multirow{2}{*}{ Property } & \multicolumn{3}{|c|}{ Cedrorana } \\
\hline & $\bar{x}$ & CV (\%) & IC \\
\hline $\mathrm{S}_{\mathrm{ef}}\left(\mathrm{mm}^{2}\right)$ & 1120.6 & 32.17 & $(919.6 ; 1303.4)$ \\
\hline $\mathrm{S}\left(\mathrm{mm}^{2}\right)$ & 349.3 & 0.26 & $(348.2 ; 349.7)$ \\
\hline $\mathrm{f}_{\mathrm{t} 0}{ }^{\mathrm{ABNT}}(\mathrm{MPa})$ & 69.3 & 18.32 & $(64.7 ; 81.4)$ \\
\hline $\left.\mathrm{f}_{\mathrm{t} 0} \mathrm{ef}^{\mathrm{MPa}}\right)$ & 24.6 & 37.15 & $(19.6 ; 29.1)$ \\
\hline \multirow{2}{*}{ Property } & \multicolumn{3}{|c|}{ Canafístula } \\
\hline & $\bar{x}$ & $\mathrm{CV}(\%)$ & $\mathrm{IC}$ \\
\hline $\mathrm{S}_{\mathrm{ef}}\left(\mathrm{mm}^{2}\right)$ & 876.4 & 28.40 & $(758.2 ; 1005.6)$ \\
\hline $\mathrm{S}\left(\mathrm{mm}^{2}\right)$ & 348.6 & 0.18 & $(347.4 ; 348.1)$ \\
\hline $\mathrm{f}_{\mathrm{t} 0} \mathrm{ABNT}(\mathrm{MPa})$ & 76.2 & 23.57 & $(60.2 ; 84.7)$ \\
\hline $\mathrm{f}_{\mathrm{t} 0}$ ef $(\mathrm{MPa})$ & 31.1 & 32.16 & $(29.9 ; 44.1 ;)$ \\
\hline \multirow{2}{*}{ Property } & \multicolumn{3}{|c|}{ Tatajuba } \\
\hline & $\bar{x}$ & CV (\%) & IC \\
\hline $\mathrm{S}_{\mathrm{ef}}\left(\mathrm{mm}^{2}\right)$ & 573.1 & 35.76 & $(527.8 ; 718.4)$ \\
\hline $\mathrm{S}\left(\mathrm{mm}^{2}\right)$ & 349.1 & 0.07 & $(349.8 ; 349.1)$ \\
\hline $\mathrm{f}_{\mathrm{t} 0}{ }^{\mathrm{ABNT}}(\mathrm{MPa})$ & 98.1 & 20.08 & $(82.3 ; 106.2)$ \\
\hline $\mathrm{f}_{\mathrm{t} 0} \mathrm{ef}_{(\mathrm{MPa})}$ & 56.4 & 43.51 & $(35.6 ; 61.4)$ \\
\hline \multirow{2}{*}{ Property } & \multicolumn{3}{|c|}{ Maçaranduba } \\
\hline & $\bar{x}$ & CV (\%) & IC \\
\hline $\mathrm{S}_{\mathrm{ef}}\left(\mathrm{mm}^{2}\right)$ & 748.3 & 27.81 & $(579.1 ; 818.2)$ \\
\hline $\mathrm{S}\left(\mathrm{mm}^{2}\right)$ & 351.3 & 0.11 & $(351.0 ; 351.6)$ \\
\hline $\mathrm{f}_{\mathrm{t} 0}{ }^{\mathrm{ABNT}}(\mathrm{MPa})$ & 126.4 & 20.21 & $(104.9 ; 148.2)$ \\
\hline $\mathrm{f}_{\mathrm{t} 0} \mathrm{ef}_{(\mathrm{MPa})}$ & 62.2 & 38.17 & $(60.9 ; 76.2)$ \\
\hline
\end{tabular}

TABLE 2. Means, coefficients of variation, and confidence intervals ( $95 \%$ confidence) of the properties $S_{e f}, S, f_{t 0}{ }^{A B N T}$, and $f_{t 0}{ }^{e f}$ for each wood species. 
Among other mechanical tests, parallel-to-grain tensile strength testing was used for the same species (among others) in a study performed by Dias \& Lahr $(2004)$. These authors found tensile strength means of 62, 85, 93, and $139 \mathrm{MPa}$ for Cedrorana, Canafístula, Tatajuba, and Maçaranduba, respectively. Such results are in accordance with ours, as shown in Table 2.

The coefficients of variation (CV) for parallel-tograin tensile strengths obtained by the Brazilian standard procedure were below $24 \%$, as established in the Brazilian norm NBR 7190 (1197), in which $18 \%$ is for normal loads and $28 \%$ for tangential requests. For the estimated strength, the lowest and highest coefficients of variation were $32.16 \%$ and $43.51 \%$, respectively. These outcomes can be justified by a large variation in cracking mode of specimens, reflecting the large range of means estimated within such confidence intervals.

All samples showed a mean fractured area 2.21 times higher than the cross-sectional area, which implies a significant reduction in tensile strength.

Using the least square method, the set of four species resulted in an $\alpha$ coefficient of $2.14\left(\mathrm{~S}_{\mathrm{ef}}=\alpha \cdot \mathrm{S}\right)$; thus, the fractured section is on average 2.14 times the crosssectional area of the tested specimens. Hence, the parallelto-grain tensile strength was $47 \%$ of the value estimated using the equation and calculation methods proposed by the current used Brazilian standard. However, this outcome falls short of what is established for the safety of structural projects.

The absence of tensile failure parallel to grain direction (beams and columns) in structural projects is certainly associated with increasing coefficients of loads and reduction of mechanical properties (stiffness and strength). This is because the failure form in a tensile element does not occur as idealized by the Brazilian standard, thus this factor must be taken into account.

\section{CONCLUSIONS}

The coefficient $\alpha$ obtained by the least square method in this study, which expresses the relationship between the cross-sectional area (S) and the approximate fractured surface in the tested wood specimens $\left(\mathrm{S}_{\mathrm{ef}}\right)$, was of 2.14. Moreover, the tensile strength estimates were $47 \%$ lower than those currently estimated by the method proposed by the Brazilian standard, thus, being unfavorable for the safety of construction structures.

The form the tested wood specimens fractured varied widely, leading to large variations in the areas. Thus, to improve the coefficient of relationship between these areas, there is still a need for further studies using significantly larger number of species and samples.

\section{REFERENCES}

ABNT - Associação Brasileira de Normas Técnicas. NBR 7190 - Projeto de estruturas de madeira. Rio de Janeiro: ABNT, 1997.

Cavalheiro RS, Calil Neto C, Christoforo AL, Calil Junior C, Lahr FAR (2016) Evaluation of shear strength and cyclic delamination of Paricá (Schizolobium amazonicum) glued laminated timber. International Journal of Materials Engineering 6:60-65.
Christoforo AL, Panzera TH, Araujo VA, Fiorelli J, Lahr FAR (2017) Timber beam repair based on polymercementitious blends. Engenharia Agrícola 37(2):366-375.

Dai D, Fan M (2014) Wood fibres as reinforcements in natural fibre composites: structure, properties, processing and applications. In: Hodzic A, Shanks R. Natural Fibre Composites: Materials, processes and applications, p 3-65.

Dias FM, Lahr FAR (2004) Estimativa de propriedades de resistência e rigidez da madeira através da densidade aparente. Scientia Forestalis (IPEF) 65:102-113.

Fank PY, Stefani PM, Piter JC (2017) Clasificación mecánica de tablas de pinos resinosos cultivados en el nordeste de Argentina. Maderas Ciencia y Tecnologia 19(3):247-264.

Icimoto FH, Ferro FS, Almeida DH, Christoforo AL, Rocco FAL (2015) Influence of specimen orientation on determination of elasticity in static bending. Maderas Ciencia y Tecnología 17:229-238.

Kain G, Barbu M C, Hinterreiter S, Richter K, Petutschnigg A (2017) Structural evaluation of a timber construction element originating from the great metéoron monastery in Greece. BioResosurces 12(2):2433-2451.

Lahr FAR, Christoforo AL, Panzera TH, Silva DAL, Goncalves D (2014) Anisotropy influence in obtaining stiffness property in bending of Brazilian wood species. International Journal of Materials Engineering 4:92-96.

Molina JC, Calil Jr.C (2015) Numerical simulation of the temperature field in a timber composite timber concrete composition cross section in fire. Journal of Civil Engineering and Architecture 2:523-533.

Morel S, Dourado N, Valentin G (2005) Wood: a quasibrittle material R-curve behavior and peak load evaluation. International Journal of Fracture 131(4):385-400.

Stolf DO, Bertolini MS, Ribeiro Filho SLM, Panzera TH, Christoforo AL, Lahr FAR (2016) Wood impregnated with methyl methacrylate. Journal of Materials in Civil Engineering 29(6):05016004-2 -05016004-6.

Stolf DO, Bertolini MS, Almeida DH, Silva DAPL, Panzera TH, Christoforo AL, Lahr FAR (2015) Influence of growth ring orientation of some wood species to obtain toughness. Rem: Revista Escola de Minas 68:265-271.

Tao L, Da-li C, Stavros A, Magnus EP, Wålinder DZ (2017) Response of hygroscopicity to heat treatment and its relation to durability of thermally modified wood. Construction and Building Materials 144(30):671-676.

Xianwu Z, Yurong W, Li W, Jianxiong LRZ (2017) Cell wall structure and mechanical properties of Salix psammophila. Wood Research 62(1):1-12.

Youjun Q, Hai F, Huiyuan S, Weiqing L, Yu B (2017) Bending performance of GFRP-wood sandwich beams with lattice-web reinforcement in flatwise and sidewise directions. Construction and Building Materials 156(15):532-545. 